$$
\begin{array}{ccccccc}
\text { L } & \text { E } & \text { T } & \text { u } & \text { v } & \text { о } & \text { s } \\
\hline \text { ARCHEOlogija } & 47
\end{array}
$$



Lietuvos istorijos institutas

\begin{tabular}{llllllll}
$\mathrm{L}$ & $\mathrm{I}$ & $\mathrm{E}$ & $\mathrm{T}$ & $\mathrm{U}$ & $\mathrm{V}$ & $\mathrm{O}$ & $\mathrm{S}$ \\
\hline
\end{tabular}

ARCHEOlogija 47 


\section{Leidybą finansavo}

\section{LIETUVOS MOKSLO TARYBA}

PAGAL VALSTYBINĘ LITUANISTINIŲ TYRIMŲ IR SKLAIDOS 2016-2024 METŲ PROGRAMĄ

(Finansavimo sutarties numeris S-LIP-19-4)

\section{Redaktorių kolegija / Editorial board:}

Atsakingoji redaktorė / Editor-in-chief dr. Agnè Čivilytė (Lietuvos istorijos institutas, Vilnius / Lithuanian Institute of History, Vilnius)

Atsakingosios redaktorès pavaduotoja / Assistant Editor dr. Elena Pranckènaitè (Lietuvos istorijos institutas, Vilnius / Lithuanian Institute of History, Vilnius)

Dr. Laurynas Kurila (Lietuvos istorijos institutas, Vilnius / Lithuanian Institute of History, Vilnius)

Dr. Valdis Bērziņš (Latvijos universitetas, Latvijos istorijos institutas, Ryga / University of Latvia, Institute of Latvian History, Riga)

Habil. dr. Anna Bitner-Wróblewska (Valstybinis archeologijos muziejus Varšuvoje, Lenkija / State Archaeological Museum in Warsaw, Poland)

Dr. Christoph Jahn (Baltijos ir Skandinavijos archeologijos centras, Šlèzvigas, Vokietija / Center for Baltic and Scandinavian Archaeology, Schleswig, Germany)

Prof. dr. Rimantas Jankauskas (Vilniaus universitetas, Lietuva / Vilnius University, Lithuania)

Akad. prof. dr. Eugenijus Jovaiša (Lietuvos mokslu akademija, Vilnius / Lithuanian Academy of Sciences, Vilnius)

Habil. dr. Bartosz Kontny (Varšuvos universitetas, Archeologijos fakultetas, Lenkija / Faculty of Archaeology, University of Warsaw, Poland)

Prof. dr. Valter Lang (Tartu universitetas, Estija / University of Tartu, Estonia)

Doc. dr. Algimantas Merkevičius (Vilniaus universitetas, Lietuva / Vilnius University, Lithuania)

Habil. dr. Tomasz Nowakiewicz (Varšuvos universitetas, Archeologijos fakultetas, Lenkija / Faculty of Archaeology, University of Warsaw, Poland)
Habil. dr. Grzegorz Osipowicz (Mikalojaus Koperniko universitetas, Torunè, Lenkija / Nicolaus Copernicus University, Toruń, Poland)

Dr. Gytis Piličiauskas (Lietuvos istorijos institutas, Vilnius / Lithuanian Institute of History, Vilnius)

Dr. Eve Rannamäe (Tartu universtitetas, Estija / University of Tartu, Estonia)

Dr. Andra Simniškyte (Lietuvos istorijos institutas, Vilnius / Lithuanian Institute of History, Vilnius)

Dr. Roberts Spirgis (Latvijos universitetas, Latvijos istorijos institutas, Ryga / University of Latvia, Institute of Latvian History, Riga)

Dr. Eugenijus Svetikas (Lietuvos istorijos institutas, Vilnius / Lithuanian Institute of History, Vilnius)

Dr. Andris Šnē (Latvijos universitetas, Ryga / University of Latvia, Riga)

Doc. dr. Gintautas Zabiela (Klaipédos universitetas, Lietuva / Klaipéda University, Lithuania)

Prof. dr. Šarūnas Milišauskas (Niujorko valstijos Bafalo universitetas, JAV / New York State University at Buffalo, USA)

Prof. dr. Timothy Chevral (Niujorko valstijos Bafalo universitetas, JAV / New York State University at Buffalo, USA)

Prof. dr. Johan Ling (Gioteborgo universitetas, Švedija / University of Gothenburg, Sweden)

Sekretorè / Secretary Dovilè Urbonavičiūtė-Jankauskienė

Redakcijos adresas / Editorial Board address:

Lietuvos istorijos institutas, Archeologijos skyrius

Tilto g. 17, LT-01101 Vilnius

Tel. (+370) 5 2614436, fax (+370) 52611433

e-mail: lietuvosarcheologija@gmail.com; civilytea@gmail.com

\section{Žurnalas registruotas: EBSCO Publishing: Central and Eastern European Academic Source European Reference Index for the Humanities and Social Sciences (ERIH PLUS)}




\section{TURINYS / CONTENT}

Agnè Čivilytė

Ernestine S. Elster

James Patrick Mallory
PRATARME் 7

FOREWORD 11

\section{MARIJA GIMBUTIENE் KAIP ASMENYBE் / MARIJA GIMBUTAS AS PERSONALITY}

MARIJA GIMBUTAS, HER EXCAVATIONS, AND THE CONCEPT OF OLD EUROPE / MARIJA GIMBUTIENĖ, ARCHEOLOGINIAI KASINĖJIMAI IR SENOJI EUROPA .15

MARIJA GIMBUTAS IN THE CLASSROOM, FIELD AND OFFICE: A SHORT PERSONAL REMINISCENCE / MARIJA GIMBUTIENE KLASĖJE, KASINĖJIMUOSE IR KABINETE: TRUMPI ASMENINIAI PRISIMINIMAI .31

Kornelija Jankauskaitė MARIJA GIMBUTIENÉ: KELIAUTOJA IR TYRĖJA / MARIJA GIMBUTAS: TRAVELLER AND RESEARCHER .43

\section{STRAIPSNIAI / ARTICLES}

Šarūnas Milišauskas MARIJA GIMBUTAS (GIMBUTIENĖ): THE BALTIC GODDESS .55 MARIJA GIMBUTIENĖ: BALTŲ DEIVE். .88

Julia Mattes

ANTHROPOMORPHIC FIGURINES, GYNOCENTRISM AND GIMBUTAS' RECEPTION INSIDE ARCHAEOLOGY AND BEYOND .91

ANTROPOMORFINĖS FIGŪRĖLĖS, GINOCENTRIZMAS IR MARIJOS GIMBUTIENĖS IDĖJOS ARCHEOLOGIJOJE BEI UŽ JOS RIBŲ 123

MELLAART, GIMBUTAS, GODDESSES, AND ÇATALHÖYÜK: EARLY ASSUMPTIONS AND RECENT PERSPECTIVES ON THE ÇATALHÖYÜK FINDS 125

MELLAARTAS, GIMBUTIENĖ, DEIVĖS IR ČATAL HIUJUKAS: PIRMOSIOS PRIELAIDOS IR NAUJAUSIA RADINIŲ IŠ ČATAL HIUJUKO APŽVALGA 143 
Sharada Srinivasan

Rasa Banytè-Rowell

Florin Gogâltan

Gytis Piličiauskas Edvardas Simčenka Justina Kozakaitè Žydrūnè Miliauskienė Giedrè Piličiauskienè Harry Kenneth Robson

Janusz Czebreszuk Agnè Čivilytė

Paulius Gritènas

Artūras Dubonis
GODDESS WORSHIP AND THE DANCING FORM: EXPLORING RITUAL IN INDIAN PREHISTORY AND SOUTH INDIAN ANTIQUITY 145 DEIVĖS GARBINIMAS IR ŠOKIO JUDESIO FORMA: RITUALAI INDIJOS PRIEŠISTORĖJE IR PIETŲ INDIJOS ANTIKOJE 164

MARIJA GIMBUTAS’ DISSERTATION AND ITS VALUE:

BURIAL CUSTOMS IN THE ROMAN IRON AGE. 167 MARIJOS GIMBUTIENĖS DISERTACIJA IR JOS SVARBA: ROMĖNIŠKOJO LAIKOTARPO LAIDOSENA 185

TRANSYLVANIA AND THE OF INDO-EUROPEAN MIGRATION PROBLEM. THE ROMANIAN PARADIGM 187 TRANSILVANIJA IR INDOEUROPIEČIŲ MIGRACIJOS PROBLEMA. RUMUNIJOS PARADIGMA 207

DONKALNIO IR SPIGINO KAPINYNŲ AKMENS AMŽIAUS ŽMONIŲ KILMÉ IR MOBILUMAS STRONCIO IZOTOPŲ ANALIZĖS DUOMENIMIS. 209

THE ORIGINS AND MOBILITY PATTERNS OF STONE AGE HUMANS FROM THE DONKALNIS AND SPIGINAS BURIAL GROUNDS ACCORDING TO STRONTIUM ISOTOPE ANALYSIS. . .232

PROFESSOR MARIJA GIMBUTAS' ADVENTURE WITH PREHISTORIC AMBER AND THE RESULTS FOR US. 235 MARIJOS GIMBUTIENÉS PRIEŠISTORINIO GINTARO TYRINĖJIMAI IR JŲ REIKŠMĖ ŠIANDIEN 247

\section{KITAIP APIE ARCHEOLOGIJĄ /} ALTERNATIVE PERCEPTIONS OF ARCHAEOLOGY

FILOSOFIJA KAIP ARCHEOLOGIJA 249

\section{RECENZIJOS / REVIEWS}

RYTIS JONAITIS, IRMA KAPLŪNAITE்.

SENKAPIS VILNIUJE, BOKŠTO GATVËJE. XIII-XV A.

LAIDOSENOS LIETUVOJE BRUOŽAI. .253

AUTORIŲ DE்MESIUI 259

GUIDELINES FOR AUTHORS 263 


\title{
MELLAART, GIMBUTAS, GODDESSES, AND ÇATALHÖYÜK: EARLY ASSUMPTIONS AND RECENT PERSPECTIVES ON THE ÇATALHÖYÜK FINDS
}

\author{
NURCAN YALMAN
}

Nişantaşı University-Istanbul, Department of History, Maslak Mahallesi, Taşyoncası Sokak, No: 1V ve No:1Y -Bina Kodu: 34481742, Sarıer-İSTANBUL/Turkey, e-mail: nurcan.yalman@nisantasi.edu.tr

Çatalhöyük East, a Neolithic site in Central Anatolia, has often been referred to as the place of the Mother Goddess. This is because of interpretations made by Mellaart, who discovered and excavated the site in the 1960s, when he discovered its striking symbolism. The female figurines among the finds are the most important reason for this fame. Therefore, various feminist groups have been attracted to this place because they perceived the site as a proof of the existence of a peaceful matriarchal community in the past. All of this is aligned with Gimbutas' peaceful era theory, which has a Mother Goddess belief. This article will explain how archaeological finds at Çatalhöyük accompanied these theories in the time of Gimbutas and Mellaart and how new studies and new perspectives have altered these assumptions.

Keywords: Neolithic Anatolia, Çatalhöyük, Mellaart, Gimbutas, Mother Goddess, Neolithic Figurines.

Čatal Hiujukas, yra neolito laikotarpiu datuojama archeologinè vietové centrinejje Anatolijoje, dažnai yra minima kaip deivès Motinos šventovè. Ši sasaja radosi dèl James'o Mellaarto interpretacijų, kurias jis pateike po atradimu ir tyrimu Čatal Hiujuke XX a. VII dešimtm. Iš rastų dirbiniu išsiskiria moters figūrèlès, ir tapusios pagrindine minètos sąsajos priežastimi. Čatal Hiujuko vietovè traukè ivairias feminisčiu grupes kaip vieta, įrodanti, jog praeityje gyvavo taiki matriarchine visuomenè. Šios idejos sutapo su M. Gimbutienes taikios eros teorija, kurioje taip pat tikima deive Motina.

Šiame straipsnyje aptariama, kaip radiniai iš Čatal Hiujuko buvo susieti su M. Gimbutienès ir J. Mellaarto teorijomis, ir kaip naujausi tyrimai ir įžvalgos pakeite minetas interpretacijas.

Reikšminiai žodžiai: neolito laikotarpio Anatolija, Čatal Hiujukas, Mellaart, Gimbutas (Gimbutienè), deivė Motina, neolito laikotarpio figūrèlès.

This paper aims to examine the Neolithic site at Çatalhöyük and the interpretation of its symbolic expression in relation to Marija Gimbutas' Mother Goddess theory and Mellaart's perspective on Neolithic religion. Recent finds and their new interpretation as well as a general overview of the symbolism of the Çatalhöyük people will be discussed.

1994 was my first year on the Çatalhöyük Research Project. One evening, a group of people visited us and asked several questions about why we were digging at this place and what our approach to the mother goddess phenomenon was. I was a student at Istanbul University at the time. As a young archaeologist, I wasn't aware of the existence of a new age mother goddess community that wants to create a link between some archaeological sites and the present in order to legitimize, reclaim, or recreate the power of women and a peaceful earth ideology. They asked the excavation team to build a temple next to the site and asked if it was a good thing to excavate the site because it could disturb the Goddess; dancing would be far better than excavating. Clearly, visiting Çatalhöyük was 
a kind of pilgrimage for them. In the beginning, all of these conversations were left for me. Some of us were a bit puzzled because we were supposed to produce scientific research and I had never thought about a prehistoric site being the subject or part of a continuing cult. It was at this time that I started to hear Marija Gimbutas' name more frequently. Before I discuss why Çatalhöyük was a focus of these Goddess communities, perhaps a general background about the site is needed.

Çatalhöyük is a large Central Anatolian Neolithic site (c. 7400-6000 BC), which owes its fame to its rich symbolic representations. These symbolic manifestations can be seen in many different archaeological finds: the wall paintings, wall reliefs, figurines, burial rites (animal and human burials), and many other things such as displayed/hidden 'things' or the presence/absence of certain 'things'. All of these offered hints about how these people perceived and interpreted the world around them, and provided enormous sources to create narratives for archaeologists and non-archaeologists in the early years of Modern Era research. As soon as the first excavations began, the results opened a vast platform for narrating the past and for many debates. It was perhaps the right moment in the history of archaeology for the emergence of approaches; the 1960's were a transitional period between Traditional Archaeology, which focused more on categorizing, cataloguing, and comparing archaeological material than explaining how people lived, and New Archaeology, which introduced anthropological perspectives to archaeology in order to explain, focusing on processes rather than on facts; it is, therefore, also known as Processual Archaeology (Binford 1962; 1968; 1972; see also Wylie 1992 for discussions).

The first excavations were conducted at Çatalhöyük in 1961-1963 and 1965 by British archaeologist James Mellaart. The density of its spectacular finds caused great amazement among archaeologists across the world, especially at a time when it was widely believed that the Neolithic period could not have existed this far west of southeast Anatolia or north Mesopotamia. The Hacilar excavations were the first to trigger this discussion in archaeology (Mellaart 1961b, 86). James Mellaart, as the site's discoverer and excavator, produced many publications, photographs, drawings, and interesting interpretations of the settlement. Some drawing-based interpretations, some of which were published without photographic or material evidence, were heavily criticized by most of his colleagues (Zangger 2019). He was expelled after the last field season because of various problems with the Turkish Ministry of Culture (Balter 2005, 45-54). In the years when he was very disappointed about having lost his marvellous discovery, he put forward more interesting, but also controversial interpretations of the symbolism of the wall paintings. He himself introduced some of the geometric motifs on the walls as predecessors of 'kilim' designs that are still in use today. In the 1980s and early 1990's he concentrated his work on folk art, focusing on traditional rug/kilim motifs. Mellaart first suggested a possible Neolithic 'kilim connection' in 1983 at the International Conference on Oriental Carpets in London. The written version of Mellaart's conference presentation was published in Bertram Frauenknecht's book, Early Turkish Tapestries (Mellaart 1984). It seems that Mellaart was quite pleased with the attention he garnered from this idea and he extended his view; late in 1989, under the auspices of Milan rug dealer John Eskenazi, he published The Goddess from Anatolia, which is all about kilims and Çatalhöyük Wall paintings (Mellaart et al. 1989), where he even suggested that the motifs drawn on Neolithic walls were like the hanging rugs, which we can see in traditional Anatolian houses, but which cannot be found archaeologically. Unfortunately, here again, the drawings he published, which predominantly depict a female figure giving birth to a ram or bull 
head, lacked archaeological evidence and also became a subject of criticism (Eiland 1990; Mallett 1990).

The relationship between Çatalhöyük and the Goddess communities was created by interpretations made by Mellaart who found some of the so-called Neolithic 'goddess' figurines in the early 1960s. However, these thoughts about a Neolithic Goddess belief system were based on female figurines from his previous excavation at Hacilar (Mellaart 1961a, 47-61) in Anatolia's Lake District. He found twenty intact clay female figurines here; he said that these figurines had provided the first ever idea of what Late Neolithic women looked like and presented them as evidence of a religion where a goddess was predominant, a goddess whom he suggested was a prototype of such later figures as Hepat, Kubaba, and Cybele (Mellaart 1961a, 61) in Anatolia. The figurines he started to uncover in the layers at Çatalhöyük were similar to those he had found at Hacılar. Consequently, he already had the idea of a 'fertility goddess' in mind when he started to excavate Çatalhöyük but this site gave him more symbolism than Hacilar, more than he could have ever hoped for. After seeing the murals, reliefs, and burials in the architectural layers, Mellaart expanded and elaborated on the belief system he had previously defined through figurines, identifying an elite class of various ranks in the Neolithic priesthood and shrines where rituals were held (Mellaart 1967, 80-82; ibid., 77-130).

The Hacılar and Çatalhöyük finds soon became a focus among social scientists for grand theories about the beginning of religions, as seen by J. Campbell's words, 'the almost forty shrines and naked goddess sculptures' (Campbell 1995, 8, 9) found at Çatalhöyük. Mellaart's interpretations of the Hacılar and Çatalhöyük figurines were considered evidence of the earliest beliefs and cults by many colleagues and they also perfectly matched Gimbutas' theory of a mother goddess; she, therefore, also frequently mentioned the symbolism of Hacilar and Çatalhöyük in her first book about the goddess theories, The Gods and Goddesses of Old Europe which was first published in 1974 (Gimbutas 1982, the second edition of the 1974 book was published under an altered name: The Goddesses and Gods of Old Europe, 56, 152, Figs. 98-99, 176) and emphasised Çatalhöyük and Hacılar in The Civilization of the Goddess (Gimbutas 1991, 7, 8, 227, 238, 255, Fig. 7-7, Figs. 7-26). In 1978, Çatalhöyük had already been added to the beginning of women's history (Barstow 1978). Gimbutas went further and took a holistic approach; in addition to the modest archaeological interpretations which describe female figurines and other symbols as goddess cult objects, she described an entire belief system and a social structure. In her second edition (1982) of The Goddesses and Gods of Old Europe, she wrote: 'The new discoveries have served only to strengthen and support the view that the culture called Old Europe was characterized by a dominance of woman in society and worship of a Goddess incarnating the Creative principle as Source and Giver of All' (Gimbutas 1982, Preface to the New Edition). She also points to a geographical location for that specific belief system and social structure. In addition, Gimbutas identified a temporal dimension for change in these specific structures that occurred in the opposite direction: 'The term Old Europe is applied to a pre-Indo-European culture of Europe, a culture matrifocal and probably matrilineal, agricultural and sedentary, egalitarian and peaceful. It contrasted sharply with the ensuing proto-IndoEuropean culture which was patriarchal, stratified, pastoral, mobile, and war-oriented, superimposed on all Europe, except the southern and western fringes, in the course of three waves of infiltration from the Russian steppe, between 4500 and 2500 BC. During and after this period the female deities, or more accurately the Goddess Creatrix in her many aspects, were largely replaced by the predominantly male divinities of the Indo-Europeans. What developed after c. 2500 вс: was 
a mélange of the two mythic systems' (ibid.). As can be seen in these explanations, according to Gimbutas' logic, there is a complete parallelism between the belief systems and the social structure. This holistic approach as well as the female depictions using figurines, pottery, etc., which were discovered at several archaeological sites, developed over time and, among the sources, Çatalhöyük became a star as its dates were quite early. Consequently, these finds convinced many to believe that once upon a time, the Mother Goddess religion and matriarchal society existed. In turn, the New Age Goddess Communities, Eco Feminists, and Gaia Movements were inspired by Gimbutas' peaceful 'Old World' and 'Goddess' ideas.

Interest in the phenomenon of a cult which is symbolized by the worship of an omnipotent mother goddess has repeated itself since the 19th century, some colleagues discussing it in detail (Bailey 1994; Talalay 1994; Meskell 1995; 1998; Newitz 2021). In the 1970s until the end of 1980s, Gimbutas was the most important theorist of the mother goddess belief which some claim is a cult continuing from the Palaeolithic to the present day. Meskell offers the idea that the growing interest in a Goddess belief today is a tendency to use the past as a historical authority for contemporary efforts to secure gender equality in spiritual and social domains Meskell $(1998,75)$. Ecofeminists and environmentalists have seen the ideal of a matriarchal and/or matrilineal society as a solution to the environmental and gender problems; the point of view of seeing the deterioration of nature and the inequality of women in parallel came to the fore in the 70s and turned into a more defined movement in the 80s when ecofeminism began to be used as a term (Thompson 2017, 3). There is a long history of considering the unity of nature and women (Elaide 2000; Thompson 2017; Zein, Setiawan 2017) together with a world ruled or dominated by women as the right and natural way. Çatalhöyük began to be an important focal point because of its early dates and its symbolism among various myths or archaeological and historical sites because it was thought to reflect or even prove the worship of the Mother Goddess. Unfortunately, it was left alone for almost 30 years after Mellaart. This abandoned archaeological site with all those traces of symbolism and mudbrick buildings decorated with wall reliefs and paintings was closed due to erosion. Therefore, soon after the archaeologists of the second project began to work at the site in 1993, the goddess communities contacted this new team.

The second excavation project (1993-2018) was started by Ian Hodder from Cambridge University at that time. Hodder, as one of the leading figures of the recent theoretical approach, known as PostProcessual or Interpretive Archaeology, has taken the interests of the goddess community and the ecofeminists very positively under 'the multivocality' concept, which was one of the key concepts of Post Processual Archaeology. These visits continued every year, with some interruptions, during my 17 years of work at Çatalhöyük. In time, a systematic sharing mode formed between them and the project team. Rountree, an anthropologist, visited the site in 2003 and worked in the 'project's community', which consists of archaeologists and specialists working together with locals in a relationship centring on the 'goddess communities'. During her research, Rountree examined the project team's responses to theories associated with the existence of mother goddess worship (Rountree 2007). She also touched upon some of the disagreements that arose between both parties, and Hodder's perspective on this multivocality experience with the goddess people. She summarized the response of the goddess community to the attitude of the team as; 'So, it is perhaps unsurprising that when Goddess visitors espouse theories different from the officially sanctioned, consensual archaeological voice, theories deemed wrong by the archaeologists, they experience frustration and sometimes anger. Some of the ways they have expressed this anger include withdrawal of their 
visits to the site for several years (there were no Goddess tours between 2001 and 2005, although individuals still visited), e-mail correspondence among women in sections of the global Goddess network, and comments in the site's visitors' book' (Rountree 2007, 17; see also (https://www.academia.edu/11575268/9_000_Years_ of_the_Goddess_in_Anatolia).

She criticized the team's understandings in respect to different groups, for instance, when Hodder invited her to create a display from the Goddess visitors' perspective, she felt very excited but soon felt disappointed because the panel allocated to them was presented as 'alternative perspectives', the main interpretation having been left for the archaeologists (Rountree 2007, 19). Her paper summarised how Hodder describes these special visitors to Çatalhöyük. An interview, in which Hodder's observations explaining that those who come here for the same purpose differ among themselves, is quite revealing. According to Hodder, there are four different perspectives among Goddess communities towards the site: "(1) the source of women's powerful experience when they visit the site, (2) the relationship between gendered social relations and the belief system in the Neolithic, (3) the relationship between material evidence and people's stories about the past, and (4) whether Goddess worship in the past means there is still a 'divine presence' at the site" (Rountree 2007, 23). She also underlined an inconsistency in what Hodder said about the archaeological findings regarding the goddess theories. In mentioning the difficulty or even impossibility of remaining neutral, objective, and distanced since any word or even data can be reinterpreted at other sites, Hodder wrote in the chapter explaining the process of developing a reflexive method in the book, Towards Reflexive Method in Archaeology: the Example at Çatalhöyük, '... As the evidence is taken by others to show that a matriarchy existed at Çatalhöyük, the archaeologist is drawn into an opinion, for or against. For example, in my view the evidence that we have gained at
Çatalhöyük suggests not an all-powerful Goddess and a priestly élite, but daily domestic rituals and a set of beliefs and myths in which both men and women play a role' (Hodder 2000b, 11). But in an interview that she conducted with him, he said 'archaeologists could say there was a powerful female deity of some sort at Çatalhöyük' (Rountree 2007, 24). Although she perceived an inconsistency in these two quotes, there is a difference between 'a belief system structured around a great mother goddess' and 'a mythological context with women, men, animals, and plants embedded in it'. I think the most fundamental distinction between the archaeologists and goddess people was about the difference between searching for any trace that can show a worship or ritual practice to a Goddess on an archaeological site and searching for any evidence that a Goddess ever existed or still exists.

It can be said that most of these discussions about a belief in a mother goddess were usually developed over figurines. Mellaart's way of generating ideas was through this group of finds. Therefore, when discussing new interpretations at Çatalhöyük, we can give them priority.

Figurines have generally been studied by researchers differently from other archaeological finds. What information figurines can provide about past societies is also a broad topic (Ucko 1962; 1968; Hamilton 1996a; Kuijt 2017). Archaeologists usually take them as a bridge for understanding the relationship between the tangible and intangible reflections of past values. Sometimes, they were interpreted as visualized and materialized representations of gods and goddesses or, more recently, toys or auxiliary materials used to practice magic. Later, figurines, especially anthropomorphic examples, have viewed from different perspectives such as whether they were mirroring an actual human body in a past community. Were they carrying some hints about what people looked like? And even more than that, were the past communities or individuals 
expressing idealistic body forms directly on the anthropomorphic figurines?

Ucko grouped the studies of figurines over a long time and critically examined both the methodological and the theoretical approaches in archaeology (Ucko 1962, 38). Meskell, who approaches figurines from a more philosophical and theoretical point of view, has discussed the changing perspectives in analyses in recent years and stressed the importance of studying the manufacturing processes starting with the raw materials. She stated that figurines have been discussed in wider contexts within archaeology and material culture, in terms of embodiment, sexuality, personality, practice, and process in time. She concludes that these human-made objects are 'things in themselves with their own spheres of interaction. By employing the notion of representation, we are able to infer that figurines stand in for something real and are a reflection of that reality, of someone or something' (Meskell 2017, 2)

Circa the mid-19th century, the interpretation of female figurines had already been begun by European Palaeolithic researchers many of whom called them Venus figurines. But recent approaches have taken a closer look at this term and according to some colleagues, naming the first female figurines 'venuses' reflects a male point of view towards these nude and vulva defined female forms (Conkey 1997, 185; Dixson, Dixson 2011). Here too, we see the tendency to interpret those 'venuses' as goddesses via Venus, the Goddess of beauty and female sexuality.

Over time, the female figurines, whose feminine features were highlighted or even exaggerated, began to be called goddesses. That these plump female figures were proof of a fertility goddess cult was even accepted with great certainty not only by the goddess communities, but also informally by the archaeologists themselves, although not necessarily in formal scientific reports.

During the seventeen years of my work at Çatalhöyük, one particular object stood out forme (not for me! - for the general audiances, for goddess people as well) among the many archaeological finds that may contain a symbolic meaning that is a focus for both feminists and goddess communities. It was a clay figurine, known well as the Mother Goddess of Çatalhöyük, which was found by James Mellaart in his 1960's excavations (Mellaart 1967, 156-157/IX, Fig. 67-68). It is a female figure which was depicted in a sovereign pose between two big felines which are interpreted as leopards. The tails of these big and probably wild cats are coiling up her shoulders. And their existence creates the effect that the stool on which this woman is sitting looks like a throne. One might ask, how else could such a depiction be interpreted other than as a Goddess who has full control over wild nature, even the most dangerous animals such as wild cats? Mellaart was probably so excited by this find that he went further by interpreting the clay lump between the woman's feet as the goddess giving birth to a male child. Of course, this was not the only female figurine Mellaart found at Çatalhöyük, just the most famous one.

He has shared his observations about the contextual information of figurines in general, dividing the figurines into ex voto and cult statues according to their contexts and quality. However, in doing so, shrine contexts were associated with all of the different figurines (animal, schematised human, etc) even though those crude clay figurines were not found inside shrines, having been found stuck between bricks or walls, because he thought these walls belonged to nearby shrines or pits (Mellaart 1967, 180). In this main publication, he reports the discovery of around fifty figurines, the female deity statues far outnumbering those of the male deity, and continues by giving some stratigraphical data (ibid., 181).

Hodder's team looked at the findings from Çatalhöyük which had been previously interpreted by Mellaart. This new team brought different perspectives and unearthed new finds that are similar 
to Mellaart's. But the novelty here is the new theoretical perspectives and the multidisciplinary approach with a large team of specialists who work at 'on-site laboratories', with more comprehensive excavation methodology and sampling strategies, and complete (?) detailed documentation. All these brought new data, especially about the contextual information, which was supported by statistical, physical, and chemical analyses (see the list of references about the Çatalhöyük Research and Excavation Project and archive reports: www catalhoyuk.com).

When Hodder and his team started the Çatalhöyük Research Project in 1993, they primarily dealt with material previously found during Mellaart's excavations. Naomi Hamilton was the expert working on figurines in those early years. In the project's first monograph (Hodder 1996b), Hamilton mentioned that she had several problems with Mellaart's names and identifications as well as with the poor documentation and contextual information for the 254 figurines and fragments that she was able to track down during this process (Hamilton 1996b, 215). In some cases, the nomenclature had to be changed because, for instance, some of the schematic figurines previously labelled ex voto by Mellaart were renamed 'humanoid', an switch from an implied default function to a form (ibid., 221, Figure 12.1, 498).

After five excavation seasons, Hamilton was able to talk about both the figurine ensemble and its context. She reports that during the new excavations, fragments of approximately 526 figurines were found (Hamilton 2005, 187). This is more than double what was found during Mellaart's excavations, although many more structures were unearthed at that time. In fast, traditional excavations, small fragments (such as a piece of a horn or a humanoid body part) can sometimes fail to be recorded. But there may also be another reason for this situation; in the 1960s, for instance, elaborated human figurines and identifiable looking figurines were preferred to the broken or 'mundane' types of pieces for documenting a site. This became clear from the figurines found by students digging through Mellaart's spoil heap within the TEMPER project (Nakamura, Meskell 2004; Çatalhöyük Archive Reports www.catalhoyuk. com). Hamilton also presented some contextual information, saying that 'most of the figurines were found in secondary depositional contexts, largely in "midden" or in post-occupation room fill ... of the 146 anthropomorphic figurines found during the recent excavations, 21 were in spaces between buildings, 23 were in midden-like fill of abandoned buildings, 29 were found in open areas, and 6 from foundation cuts' (Hamilton 2005, 192, Table 9.3), adding 'This is completely at odds with the previous interpretations of Çatalhöyük figurines, most of which regard them as religious items found in situ in shrines' (ibid.). In summary, the figurines were re-evaluated by the new team because the context and statistical information were not clearly revealed by the previous excavations, which gave rise to different interpretations and, moreover, new research questions.

In 2004, Meskell and Nakamura begun working with Çatalhöyük figurines and their perspective became to 'decentre the figurines as art and religion'. They explained that their perspective would create areas, such as self-reflection and negotiating selfsexuality or the world between human and animal, which could be approached more easily than by defining the religion of a Neolithic society (Meskell $2007,143)$. She clearly reveals the direction of the new perspective with these words: 'I would like to move away from the sterile attempts to deduce function and meaning from a visual reading, the Is it a deity or not?' type of equation. Instead, I want to work around the objects, weaving together patterns of figurine making, technology, use, mobility, and discard, coupled with the traversing of categories from figures to plastered features to wall paintings. In this way I hope to build up more of a life-world for the Neolithic community, taking into account the inherent visuality and materiality of a figured corpus' (ibid.). These new 


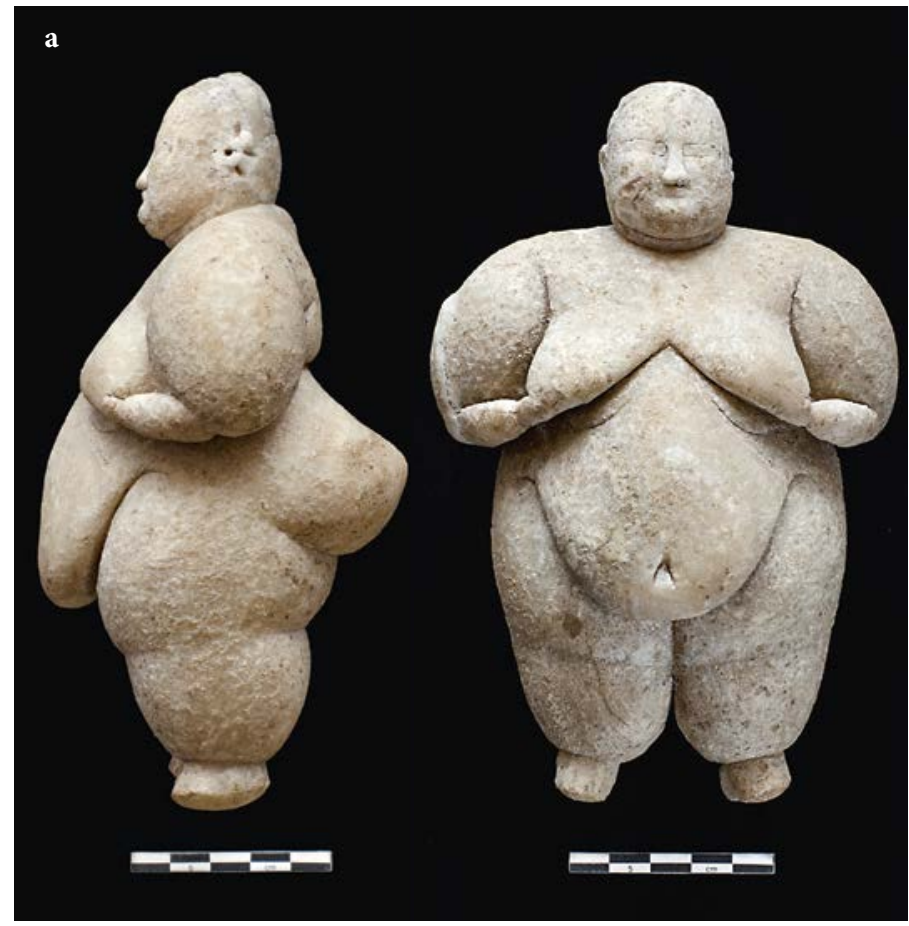

Fig. 1a. Marble female figurine found in situ (Çatalhöyük Research Project Archive). Photo by Jason Quinlan.

la pav. Marmurinè moters figūrèlè, rasta in situ (Čatal Hiujuko tyrimų projekto archyvas). Jason Quinlan nuotr.

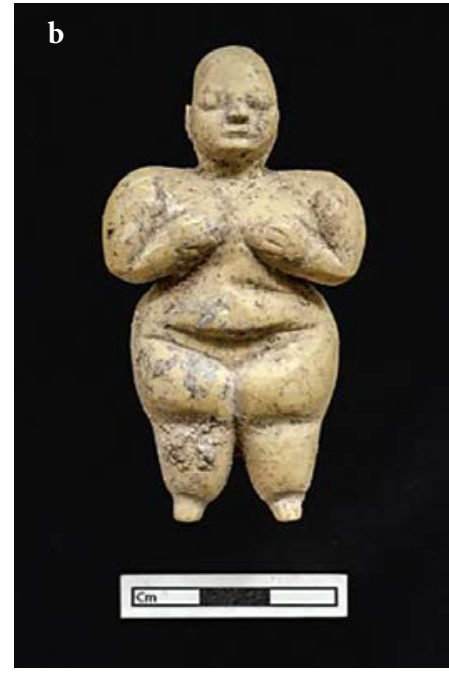

Fig. 1b. Lime stone female figurine found in situ (Çatalhöyük Research Project Archive). Photo by Jason Quinlan.

1b pav. Klintinė moters figūrèlè, rasta in situ (Čatal Hiujuko tyrimų projekto archyvas). Jason'o Quinlan'o nuotr. perspectives may now make it possible to summarize our changing knowledge of the figurines.

Meskell points out that the figurines are not rare objects in the settlement and that there are many figurine fragments in the settlement. Considering that at least 2994 (as of 2017) pieces of Neolithic figurines have been recorded and 2027 of them are figural forms excavated by the Hodder team between 1993 and 2017 (Nakamura 2021, 98), these 'things' in Çatalhöyük were a rather ordinary type of material. This view is likewise supported by the fact that they are found in secondary contexts such as room fills, middens (also rubbish areas), between walls, and so on; the majority are found in external (78\%) rather than internal (inside buildings) contexts (22\%) (see also Tables 5.1, 5.2, and 5.3 in Nakamura 2021). When Meskell and Nakamura focused on more about the "extraordinary ordinariness of the figurines" and when they stressed about the Çatalhöyük figurines do not easily accommodate narratives of the sacred or the sublime because even the buildings (such as B.77 and B.52) which were burned and preserving the household features and objects, they have not located complete figurines on floors, platforms or in niches (Nakamura, Meskell 2013); two female figurines made of stone found in situ in Building 150. This brought very interesting and different interpretations, because they seem to be placed in ritualized act (Meskell et al. 2016) (Fig. 1a-b). First of all, these very well shaped figurines were deliberately placed in the building platform, associated with other finds such as beads, obsidian blade and a piece of galena (2016 Çatalhöyük Archive Report). But still the contextual placements of the figurines are quite different then what early works of Mellaart (1967) suggested. Moreover, the wear marks on the figurines make us think that they 
were mobile, possibly carrying with or on the people (like necklaces) rather than shrine offerings or ex votos (Meskell 2017, 13).

On the other hand, the last works of Meskell and Nakamura (Nakamura 2021) still show the percentage of the secondary contexts contains figurines are the majority with $78 \%$. In that sense, Meskell relates figurines to individuals and interpret figurine making as a mundane practice and noted that the female figurines which are the focus of the goddess people, are not the dominant form in the corpus. Another alternative interpretation came from Meskell and Nakamura on the female figurines that has highlighted breasts, stomachs and so on which usually interpreted as representation of "fertility", without completely excluding this idea, it may also point out the "maturity"; because usually these body parts are depicted as flattened, drooping and angular rather than robust and rounded in shape (Nakamura, Meskell 2009, 219-220).

They have rarely been found on or near floors, which differs greatly from what Mellaart's early works (1967) proposed. Moreover, the wear marks on the figurines suggest that they were mobile, possibly being carried by or on the people (Meskell 2017, 13). In that sense, Meskell associates these figurines with individuals and interprets figurine making as a mundane practice and female figurines as not being the dominant form in the corpus. Meskell and Nakamura likewise proposed an alternative interpretation for the female figurines with an emphasis on breasts, stomachs, and other features usually interpreted as representing 'fertility'; without completely excluding this idea, 'maturity' may also be put forward because these body parts are usually depicted as flattened, drooping, and angular rather than robust and rounded (Nakamura, Meskell 2009, 219-220).

Most of the figurines at Çatalhöyük are zoomorphic (54\% in total, 35\% horned and 19\% quadrupeds), followed by abbreviated forms (24\%)

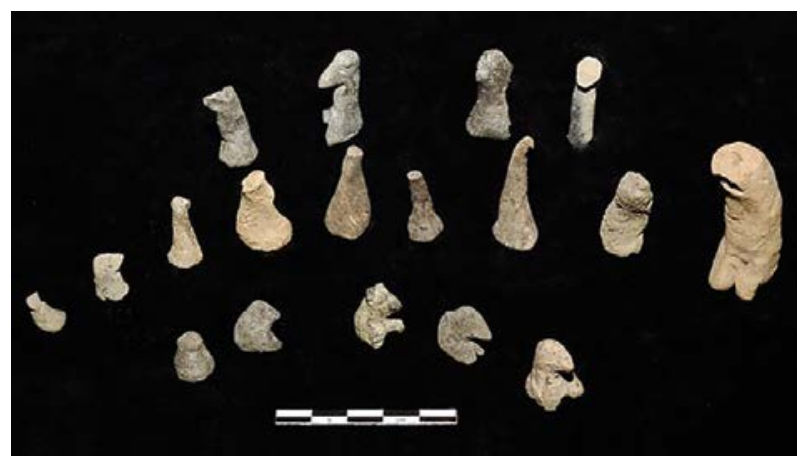

Fig. 2. Group of clay abbreviated figurines (Çatalhöyük Research Project Archive, after Nakamura, C., Meskell, L., 2009). Photo by Jason Quinlan.

2 pav. Nepilnų molinių figūrèlių rinkinys (Čatal Hiujuko tyrimų projekto archyvas, pagal Nakamura, Meskell 2009). Jason'o Quinlan'o nuotr.

(Fig. 2) and anthropomorphic forms (just 8\%) (ibid.,102). The abbreviated forms were categorized as a subgroup under the anthropomorphics but then Nakamura said they were actually closer to animallike types with phallic forms (ibid.). The overall corpus includes only certain body parts such as the aforementioned horns as well as buttocks, breasts, bellies, and sometimes phalluses (Nakamura, Meskell $2009,211,217)$. The figurine team also pointed out the stratigraphical occurrences of the finds; for instance the density and number of figurines in every category increase in the final occupation level, which might explain the smaller volume of sieved soil in the later levels compared to the early levels as well as the increase in anthropomorphic forms (Nakamura 2021, 102).

Mellaart (1967) associated figurines, and some other finds such as wall decorations, with temples or shrines, although the opinion of the new team also differs from Mellaart's in respect to the existence of shrines.

The previous interpretations led the team to check the social hierarchy, the role of woman and man, the existence of priest or priestess elites at Çatalhöyük, and the designation of some buildings 


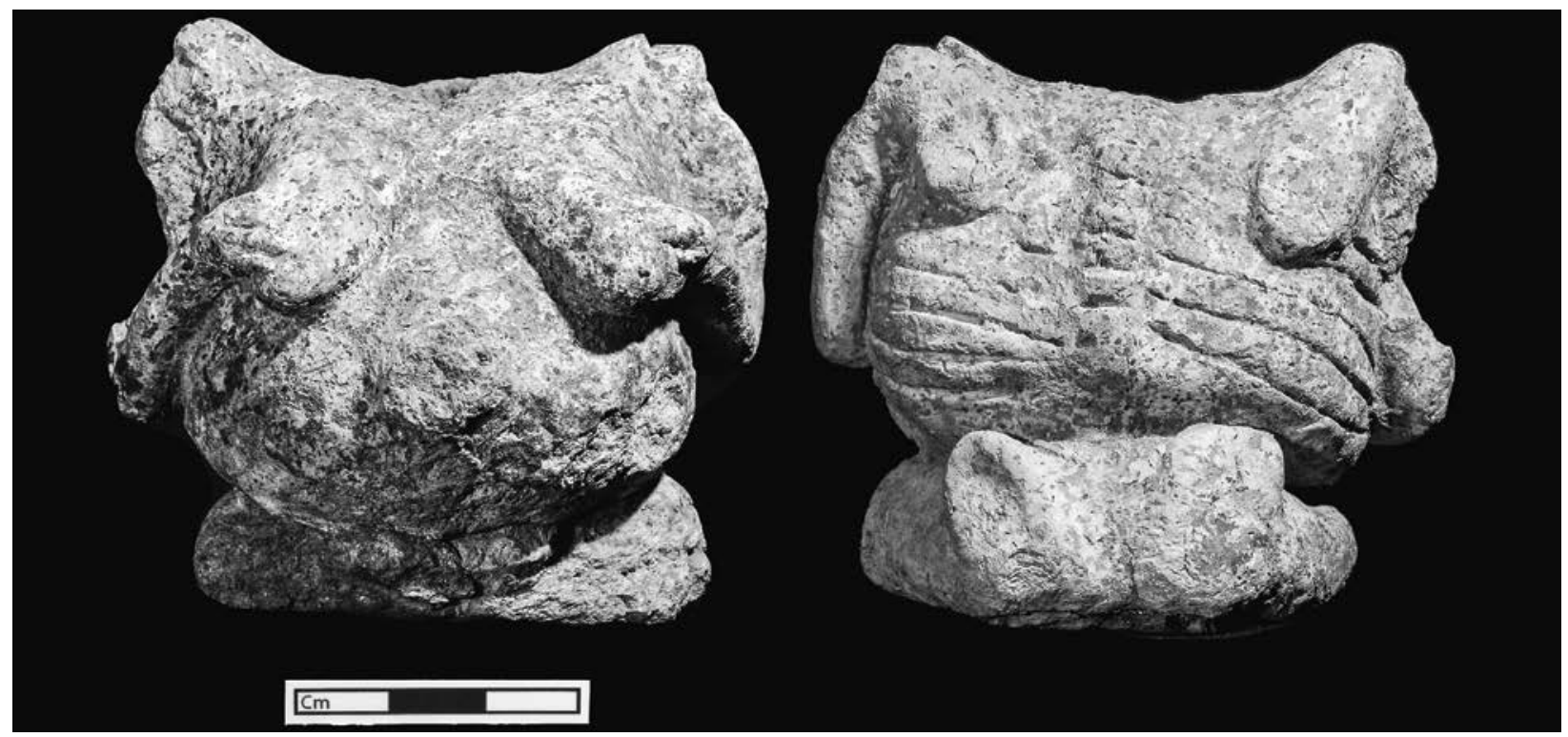

Fig. 3. Headless female figurine with the hole for a portable head, depicted as pregnant and skeleton in different sides (Çatalhöyük Research Project Archive). Photo by Jason Quinlan.

3 pav. Begalvès moters figūrèlè (su anga nuimamai galvai uždèti). Iš priekio moteris vaizduojama něščia, iš užpakalio - kaip griaučiai (Čatal Hiujuko tyrimų projekto archyvas). Jason'o Quinlan'o nuotr.

as temples or shrines. All of the decorated buildings so named by Mellaart showed evidence of domestic activities according to the new research (Matthews et al. 1996; Hodder 2014, 4), which became clear after detailed analyses of the floor layers and wall plaster layers. While conceptually disapproving of the term of 'shrine', B. During agrees with the differences what Mellaart sees between a 'house' and a 'shrine'. According to him, shrine simply means a place where rituals and religious activities take place but in the Neolithic, things like 'domestic' and 'religious' could not be separated as clearly as they are today, and so these structures may have assisted in providing a group identity (During 2001, 10). All these thoughts which are connected with the differences between the buildings in terms of the decoration level and the number of the burials, led to a new hypothesis called 'History Houses' (Hodder, Pels 2010). Those 'houses' that were continually rebuilt in the same place and include large numbers of burials with grave goods have been termed 'history houses' at Çatalhöyük.
Although the figurines show features that can be defined as mundane, ordinary, and mobile; anthropomorphic forms are found in buildings by marginally the largest percentage (Nakamura 2021,98). In general the figurines are also connected with the symbolism seen throughout the settlement. For instance, the removal and circulation of the human heads (skulls) in the burials is interestingly repeated in the figurines. The holes in some of the anthropomorphic figurines indicate that the head was removable. This pattern continues in the animal heads, usually of wild beasts, which were plastered and hung on the interior walls of the buildings. Their horns were attached to the benches and we see animal horns (not pieces broken from an animal figurine but items formed separately as just a horn) among the figurines (Russell, Meece 2006, 217-19). The heads, hands, and feet of the wall reliefs, which Mellaart interpreted as the mother goddess who gave birth, have also been destroyed. The so-called 'vulture' wall painting shows birds attacking headless humans. 
Even though we do not know the exact meaning of the skull removal, which was not practiced on all of the skeletons, but only on some, the figurines in which the head could probably be removed and put on, as the hole between shoulders possibly indicates a detachable head and neck, makes us think there could have been a connection between the dead and the figurines (Meskell 2017, 15). On the other hand, one headless (but with a corresponding hole) female figurine had very unusual details, which reflect a dead body-figurine connection (Fig. 3). In this unique example, the woman is visibly pregnant as the belly and navel appear to protrude in front, while the back is depicted as a skeleton (Meskell et al. 2015, 140; Meskell 2017). Two female stone figurines found in Building 150 in 2016 led to very interesting and different interpretations because they seem to have been placed there during a ritualized act (Meskell et al. 2016, 141). These very well shaped figurines had been deliberately placed on the building's platform, which is connected with other finds such as beads, an obsidian blade, and a piece of galena. The platforms are also burial sites. Considering the contextual relations of these figurines and the other connections noted above, the specialists suggested a possibility that some figurines depicted dead individuals (ibid.). Although the figurines are absent in the burial contexts, this applies to the fill directly related to the skeleton. 100 figurine fragments have been found in burial fills and by far the greatest percentage (73\%) consists of horns and horn fragments (Nakamura $2021,100)$. This high percentage obviously needs to be taken into considered. Nakamura suggests that the high occurrence of these horn figurines 'may suggest that they provided a kind of apotropaic function or were a symbolic "offering" or tools for "invoking" the power or presence of the wild or even a specific animal' (Nakamura 2021, 101).

Furthermore, as a result of applying different viewpoints and methodologies together with a multidisciplinary team effort, they seem to have more

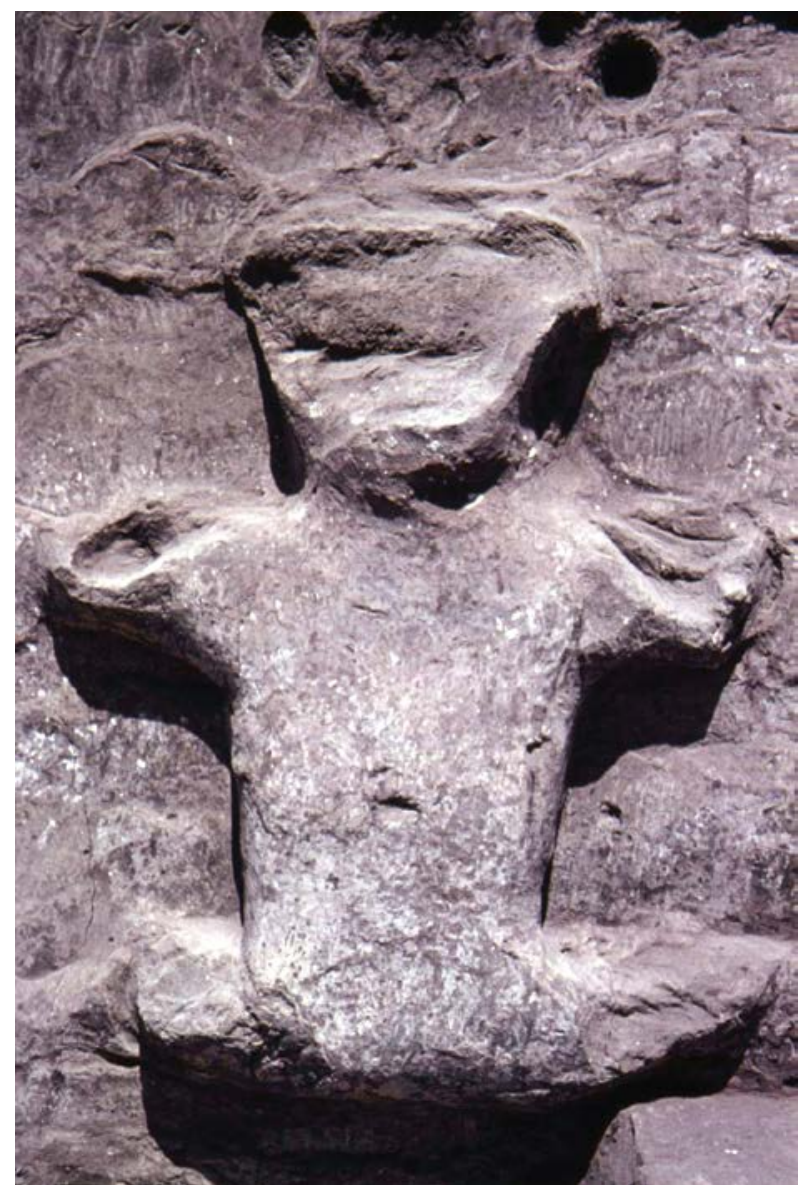

Fig. 4a. Splayed wall relief, found in 1960s excavations (Çatalhöyük Research Project Archive). Photo by Ian Todd. 4a pav. Skulptūrinis reljefas, rastas $1960 \mathrm{~m}$. kasinejjimų metu (Čatal Hiujuko tyrimų projekto archyvas). Ian'o Todd'o nuotr.

to tell us beyond the old stereotypical interpretations. Since what we are looking for here is a way to distinguish the Çatalhöyük people's Neolithic way of thinking, it is important to evaluate the figurines in relation to the many other finds and to seek connections among them.

If we return to the previous matriarchal or women-dominant social structure idea, we can say that there have also been some changes in the light of the new perspectives on the social structure.

The Çatalhöyük burials give us an important set of data when questioning the existence of the matriarchal or women-dominated social structure 


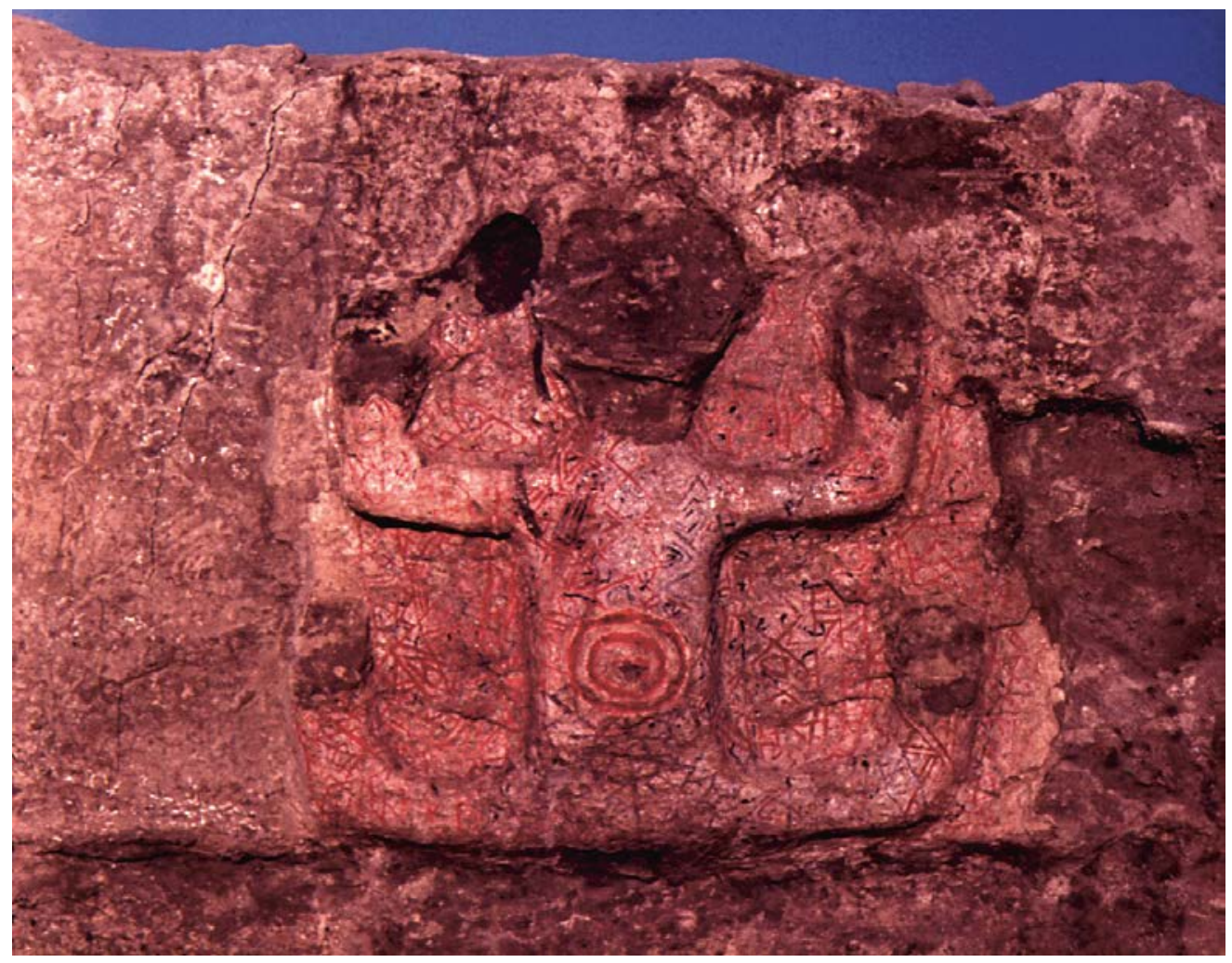

Fig. 4b. Splayed wall relief, with painted concentric circle on the belly, found in 1960s excavations (Çatalhöyük Research Project Archive). Photo by Ian Todd.

$4 \mathrm{~b}$ pav. Skulptūrinis reljefas, vaizduojantis išsikišusi pilvą su pieštais koncentriškais apskritimais. Rastas $1960 \mathrm{~m}$. kasinejjimų metu (Čatal Hiujuko tyrimų projekto archyvas). Ian'o Todd'o nuotr.

that Gimbutas and Mellaart suggested or implied. The evidence from several directions of recent research such as human bone, stable isotope, and dental analyses show that genders were not treated differently in terms of their share of the labour or work, nutritional habits, etc. Similarly, the burial data and the treatment of the individual bodies confirms this lack of differentiation between the sexes; in regard to the placement, posture, and directionality, there are no marked differences as Mellaart (1967) once claimed (Molleson et al. 2005; Hodder 2006; 2014).

Another archaeological find that Mellaart especially emphasized in terms of reflecting the mother goddess belief is the splayed figures on the wall reliefs. He argues that these depict the goddess giving birth to a bull or ram head. He even insists that the very well known 'hand on hips' motif seen in Turkish carpets and kilims also has its origin in the Çatalhöyük wall paintings, as was mentioned in the first part of this paper. Hodder's team approached these interpretations by questioning and reexamining the original data which was provided by Mellaart's excavations. Russell and Meece explained the difficulties they experienced in re-evaluating Mellaart's data:

'Most reliefs are also fragmentary and Mellaart reconstructs many from a few pieces or even from scars on the walls. We have used photographs as far as possible to judge what remained, but where photographs are not available and Mellaart does not specify the evidence for his reconstruction we have 


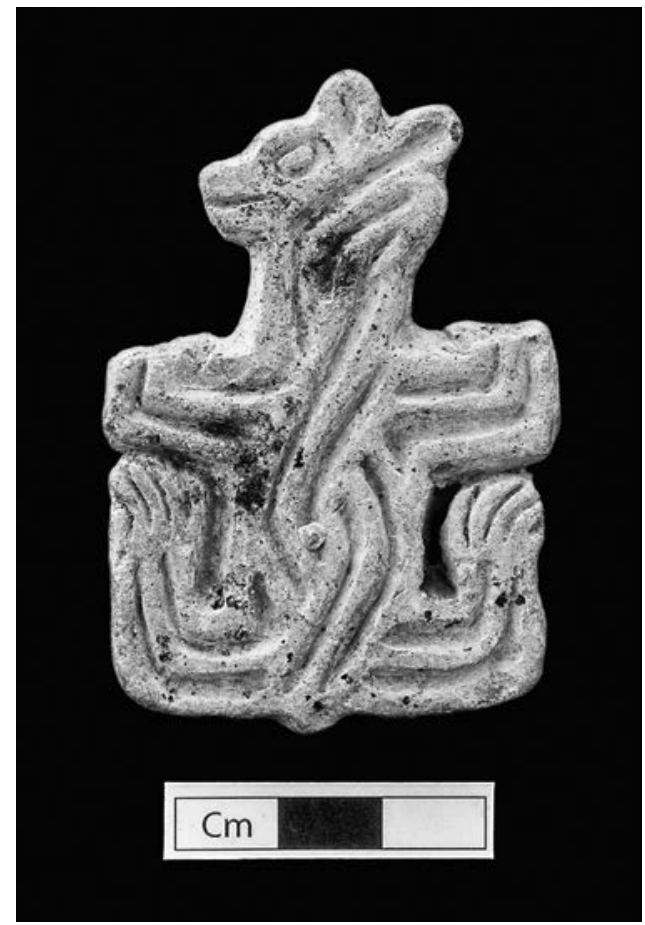

Fig. 5. Clay stamp seal interpreted as bear (Çatalhöyük Research Project Archive). Photo by Jason Quinlan.

5 pav. Molinis antspaudas, laikomas meškos atvaizdu (Čatal Hiujuko tyrimų projekto archyvas). Jason'o Quinlan'o nuotr.

been forced to accept his description at face value. We have rejected some questionable claims of wavy horns or faint indications of animal heads that appear to have resulted from slumping of the wall plaster. We also exclude Mellaart's plaster cut-out figures. Most or all of these seem to result from random plaster fall or scars left by the removal of reliefs. It is not always possible to distinguish where Mellaart has restored fallen pieces to their place on the wall and where he has supplied them by analogy to finds elsewhere on the site' (Russell, Meece 2006, 210).

The two authors explained that the reason for conducting the study of the animal representations on the overall symbolism at Çatalhöyük was to understand the animal-human relationship which is important in order to obtain insights into the social functioning because it is difficult to extrapolate how animals were perceived in the human world by examining only animal bones (ibid.). They studied the wall paintings, reliefs, figurines, etc. Here I would like to focus on some specific wall reliefs which are known as the 'splayed figures'. These reliefs, thought to be stylized females with outstretched and upturned limbs by Mellaart, do not bear any indication of gender in contrast to some of the figurines (Fig. 4a-b). Russell and Meece state that the posture described here is an impossible position for the human body and that this configuration of the limbs evokes a bear or other quadruped. Although the head and the ends of the limbs have been lost, the round head and, in some samples, even the round ears are still visible (see photo) (Fig. 4a). In addition, a slightly different version of a very similar one is depicted as a tailed animal on one of the pillars at Göbekli Tepe a PPNA-B Neolithic site in southeast Turkey (Russell, Meece 2006; Schmidt 2012; Dietrich, Notroff 2016, Fig. 7, 8). An interesting detail on these splayed figures is a distinctly marked navel; one of them has a painted concentric circle on the belly around the navel (Fig. 4b) (Russell, Meece 2006 215-216) which makes the interpretations even more complicated: were these figures intended to be animal or human or a mixture (ibid.). Surprisingly, in 2005, a clay stamp seal found in the South Area in a building fill of Level $\mathrm{V}$ bore an image strikingly similar to those of the splayed figures, even including the carefully depicted navel, but luckily with the head and lower limb ends still intact (Fig. 5). It clearly shows that this is an animal, probably a bear as shown by the hind paws, ears, and face (Hodder 2005, Çatalhöyük Archive Reports; Türkcan 2007). It turns out that the stamp seal must have been found after Russell and Meece sent their paper to the publisher because they had only speculated (but we now know) that the splayed figures might be bears.

This stamp seal is not the only finding of bears at Çatalhöyük. In Building 24 that belongs to Level VII, an articulated bear claw was found. The plaster remnants found between the toes indicate that the 
claw probably fell from where it was attached to the wall (Russell, Martin 2005, 62, Russell, Meece $2005,221)$ possibly a part of a wall decoration. This shows that the bear as an animal has a special place in Çatalhöyük people's symbolism. On the other hand, Türkcan mentions that the bear stamp seal represents a male image rather than the female deity, as criticized by Marler and Haarman (Türkcan 2007, 48; Marler, Haarmann 2007, 51). Marler and Haarman in their paper gathered various examples to support the idea that the bear and mother images are related in many archaeological and ethnographical cultures (Marler, Haarmann 2007). However, I think that both arguments made for the stamp seal and the splayed figures of the wall reliefs are not convincing enough; because the gender of the bear of the stamp seal is not clear, neither its relationship with the mother goddess nor its being a male image can be supported by the evidence so far.

\section{CONCLUSION}

The extremely complex symbolism expressed by the people of Çatalhöyük still remains unique today. Despite the highly detailed, multidisciplinary studies and the theoretical and philosophical approaches, it still seems far from easy to understand how these people, who lived among adjacent earthen structures on the Konya Plain, perceive themselves and their environment thousands of years ago. Especially in the early 1960s when James Mellaart first discovered the existence of this place, it is impossible to fail to understand the amazement of many intellectual audiences all around the world, especially the prehistoric archaeologists who specialized in the Mediterranean, European, and the Near Eastern regions.

The years in which Mellaart's first results began to appear were also a time when many other new ideas and attitudes emerged in archaeology. The 1960s was a time when archaeology got closer to anthropology, which means closer to being explanatory rather than descriptive, a time when feminism was getting stronger in waves, and it was the adult years of a traumatized generation who had seen a world war. Therefore, it is quite understandable that these two archaeologists, Gimbutas and Mellaart, who have magnificent imaginations, favour the existence of a belief in a safe, peaceful world which was ruled by a goddess who is mighty enough to sustain this environment and nature.

Although it is not the right approach to present archaeological evidence in a way that confirms an imaginary past (or even sometimes modify it), a criticism many colleagues rightly made, I think it is unfair to say that their compelling interpretations have made no contribution at all to the current perspectives in our profession or have not helped to diversify the research questions, even for those specialists who are sceptical of their theories.

In summary, everybody agrees that the finds recovered by the Mellaart and Hodder excavations show that the female form, especially in the figurines, is an important abstraction associated with a woman who might be related to some sort of a belief or a reflection of a myth, but, at the same time, there are many other forms that open up different narratives. Meskell and Nakamura understood the figurines as 'things in themselves with their own spheres of interaction' (Meskell 2017). These small things seem usually abundant and discardable, except, in rare occasions, the deliberately placed ones. Nakamura said (Nakamura 2010, 302-303) that 'figurine practices seemed valuable as a means to various ends; they encompassed a range of practices that consistently did not include the object itself, being treated with the kind of care seen with other materials.'

What the specialists, excavators, methodology developers, and all the people who came together to interpret this massive body of data here in Hodder's team show is that we should first acknowledge how 
complex the mind set of Neolithic societies was. Then we should realize how traditional methods and stereotypical conclusions prevent us from spotting the traces of many interrelated structures (Hodder 2016).

\section{REFERENCES}

Bailey, D. W., 1994. Reading Prehistoric Figurines as Individuals. World Archaeology, 25 (3), 321-331.

Balter, M., 2005. The Goddess and the Bull. Catalhöyük: An Archaeological Journey to the Dawn of Civilization. New York: Free Press.

Barstow, A., 1978. The Uses of Archeology for Women's History: James Mellaart's Work on the Neolithic Goddess at Çatal Hüyük. Feminist Studies, 4 (3), 7-18. DOI: https://doi.org/10.2307/3177535.

Binford, L. R., 1962. Archaeology as Anthropology. American Antiquity, 28 (2), 217-225. DOI: https://doi. org/10.2307/278380.

Binford, L. R., 1968. Some Comments on Historical versus Processual Archaeology. Southwestern Journal of Anthropology, 24 (3), 267-275.

Binford, L. R., 1972. An Archaeological Perspective. New York: Academic Press.

Campbell, J., 1995. İlkel Mitoloji: Tanrının Maskeleri (Turkish translation of the 1969 edition of The Masks of God: Primitive Mythology). İmge Kitabevi.

Conkey, M. W., 1997 Mobilizing Ideologies: Paleolithic 'Art' Gender Trouble, and Thinking About Alternatives. In: Hager, L., (ed.). Women in Human Evolution. London: Routledge, 172-207.

Dietrich O., J., Notroff, J., 2016. A Decorated Bone ,Spatula' from Göbekli Tepe. On the Pitfalls of Iconographic Interpretations of Early Neolithic Art. Neo-Lithics 1, 22-31.

Dixon, A., Dixon, B., 2011. Venus Figurines of the European Paleolithic: Symbols of Fertility or Attractiveness? Journal of Anthropology, 1-11. DOI: https://doi.org/10.1155/2011/569120.
During, B., 2001. Social dimensions in the architecture of Neolithic Çatalhöyük. Anatolian Studies, 51, 1-8. DOI: https://doi.org/10.2307/3643025.

Eiland, M., 1990. The Goddess from Anatolia. Review by Murray Eiland. Oriental Rug Review, 10, 6, 19-26.

Elaide, M., 2000. Dinler Tarihine Giriş (Introduction to the History of Religions). İstanbul: Kabalc1.

Gimbutas, M., 1982 [1974]. The Goddesses and Gods of Old Europe: 6500-3500 bc Myths and Cult Images. University of California Press.

Gimbutas, M., 1991. The Civilization of the Goddess. Marler, J., (ed.). San Francisco: HarperCollins.

Hamilton, N., 1996a. Can we interpret figurines? Cambridge Archaeological Journal, 6 (02), 281-307.

Hamilton, N., 1996b. Figurines, Clay Balls, Small Finds and Burials. In: Hodder, I., (ed.). On the Surface: Çatalhöyük 1993-95. Cambridge: McDonald Institute for Archaeological Research, 215-263.

Hamilton, N., 2005. The Figurines. In: Hodder, I., (ed.). Changing Materialities at Çatalhöyük: reports from the 1995-99 seasons by members of the Çatalhöyük teams (=Çatalhöyük Research Project Volume 5). London: British Institute at Ankara, 187-213.

Hodder, I., (ed.), 1996. On the Surface: Çatalhöyük 1993-95. Cambridge: McDonald Institute for Archaeological Research.

Hodder, I., (ed.), 2000a. Towards Reflexive Method in Archaeology: The Example at Çatalhöyük. Cambridge: McDonald Institute for Archaeological Research.

Hodder, I., 2000b. Developing a reflexive method in archaeology. In: Hodder, I., (ed.). Towards Reflexive Method in Archaeology: The Example at Çatalhöyük. Cambridge: McDonald Institute for Archaeological Research, 3-14.

Hodder, I., 2005. Çatalhöyük Archive Reports. Available from: http://www.catalhoyuk.com/ archive_reports/pdf2005). 
Hodder, I., 2006. The Leopard's Tale: Revealing the Mysteries of Çatalhöyük. London: Thames \& Hudson.

Hodder, I., 2014. Çatalhöyük: the Leopard Changes its Spots. A Summary of Recent Work. Anatolian Studies, 64, 1-22. DOI: https://doi. org/10.1017/S0066154614000027.

Hodder, I., 2016. Studies in Human-Thing Entanglement. Online Book, available from: http://www.ian-hodder.com/books/studies-human-thing-entanglement.

Hodder, I., Pels, P., 2010. History houses: A new interpretation of architectural elaboration at Catalhoyuk. In: Hodder, I., (ed.). Religion in the Emergence of Civilization: Çatalhöyük as a Case Study. Cambridge University Press, 163-186.

Kuijt, I., 2017. Clay Ideas: Levantine Neolithic Figurine Trajectories and Intellectual Threads. In: Insoll, T., (ed.). The Oxford Handbook of Prehistoric Figurines. Oxford Handbooks Online. DOI: 10.1093/ oxfordhb/9780199675616.013.028.

Mallett, M., 1990. A Weaver's View of the Çatalhöyük Controversy. Oriental Rug Review, 10, 6, 32-43.

Marler, J., H. Haarmann, H., 2007. The Goddess and the Bear Hybrid Imagery and Symbolism at Çatalhöyük. The Journal of Archaeomythology, 3, 48-79.

Matthews, W., French, C., Lawrence, T., Cutler, D. F., 1996. Multiple Surfaces: the Micromorphology. In: Hodder, I., (ed.). On the Surface. Çatalhöyük 1993-1995. Cambridge: McDonald Institute for Archaeological Research, 301-342.

Mellaart, J., 1961a. Excavations at Hacılar: Fourth Preliminary Report, 1960. Anatolian Studies, 11, 3975. DOI: https://doi.org/10.2307/3642456.

Mellaart, J., 1961b. Hac1lar: A Neolithic Village Site. Scientific American, 205, 2, 86-98.

Mellaart, J., 1967. Çatal Hüyük: A Neolithic Town in Anatolia. London: Thames and

Mellaart, J., 1984. Some notes on the prehistory of Anatolian Kilims. In: Frauenknecht, B., (ed.). Early Turkish Tapestries. Nürnberg: B. Frauenknecht, 25-41.
Mellaart, J., Balpinar, B., Hirsch, U., 1989. The Goddess from Anatolia. Milan: Eskenazi.

Meskell, L., 1995. Goddesses, Gimbutas and Archaeology 'New Age' Archaeology. Antiquity, 69, 262, 74-86. DOI: https://doi.org/10.1017/ S0003598X00064310.

Meskell, L., 1998. Oh my Goddess! Archaeology, Sexuality and Ecofeminism. Archaeological Dialogues, 5 (2), 126-142. DOI: https://doi.org/10.1017/ S1380203800001264.

Meskell, L., 2007. Refiguring the Corpus at Çatalhöyük. In: Renfrew, C., Morley, I., (eds). Material Beginnings: A Global Prehistory of Figurative Representation. Cambridge: McDonald Institute Monographs, 143-156.

Meskell, L., 2017. The Archaeology of Figurines and the Human Body in Prehistory. In: Insoll, T., (ed.). The Oxford Handbook of Prehistoric Figurines. Oxford Handbooks Online. DOI: 10.1093/ oxfordhb/9780199675616.013.002.

Meskell, L., Nakamura, C., 2015. Figurines. Çatalhöyük Archive Report. Available from: http:// www.catalhoyuk.com/sites/default/files/media/pdf/ Archive_Report_2015.pdf.

Meskell, L., Nakamura, C., Tsoraki, C., Arnts, M., 2016. Figurines. Çatalhöyük Archive Report. Available from: http://www.catalhoyuk.com/sites/ default/files/media/pdf/Archive_Report_2016.pdf.

Molleson, T. I., Andrews, P., Boz, B., 2005. Reconstruction of the Neolithic People of Çatalhöyük. In: Hodder, I., (ed.). Inhabiting Çatal höyük: Reports from the 1995-99 Seasons. Cambridge: McDonald Institute for Archaeological Research, 279-300.

Nakamura, C., 2010. Magical Deposits at Çatalhöyük: A matter of time and place? In: Hodder, I., (ed.). Religion in the Emergence of Civilization: Çatalhöyük as a Case Study. Cambridge University Press, 300-331.

Nakamura, C., 2021. Figuring Diversity: the Neolithic Çatalhöyük Figurines. In: Hodder, I., (ed.). 
The Matter of Çatalhöyük: Reports from the 2009-2017 Seasons. British Institute at Ankara, 97-131.

Nakamura, C., Meskell, L., 2004. Çatalhöyük Archive Reports. Available from:

http://www.catalhoyuk.com/sites/default/files/media/ pdf/Archive_Report_2005.pdf.

Nakamura, C., Meskell, L., 2009. Articulate Bodies: Forms and Figures at Çatalhöyük. Journal of Archaeological Method and Theory, 16, 205-230.

Nakamura, C., Meskell, L., 2013. Figurine Worlds at Çatalhöyük. In: Hodder, I., (ed.). Substantive Technologies at Çatalhöyük: Reports from the 20002008 Seasons. Los Angeles: Cotsen Institute UCLA, 201-234.

Newitz, A., 2021. What Archaeologists Got Wrong about Female Statues, Goddesses, and Fertility. Popular science, available from: https://www.popsci.com/story/science/ ancient-statues-misinterpreted-by-historians.

Rountree, K., 2007. Archaeologists and Goddess Feminists at Çatalhöyük: An Experiment in Multivocality. Journal of Feminist Studies in Religion, 23 (2), 7-26.

Russell, N., Martin, L., 2005. The Çatalhöyük mammal remains. In: Hodder, I., (ed.). Inhabiting Çatalhöyük: reports from the 1995-1999. British Institute of Archaeology at Ankara, 33-98.

Russell, N., Meece, S., 2006. Animal representations and animal remains at Çatalhöyük. In: Hodder, I., (ed.). Çatalhöyük Perspectives: Reports from the 1995-1999 Seasons. Cambridge: McDonald Institute for Archaeological Research, 209-230.

Schmidt, K., 2012. Göbekli Tepe. A Stone Age Sanctuary in South-Eastern Anatolia. Heidelberg: ArchaeNova.
Talalay, L. E., 1994. A Feminist Boomerang: The Great Goddess of Greek Prehistory. Gender and History, 6 (2), 165-183. DOI: 10.1111/j.1468-0424.1994. tb00001.x.

Thompson, J., 2017. Ecofeminism: The Path towards Healing the Earth. Dialogue \& Nexus, 4, 1-7.

Türkcan, A. U., 2007. Is it Goddess or Bear? The Role of Çatalhöyük Animal Seals in Neolithic Symbolism. Documenta Praehistorica, XXXIV, 257-266.

Ucko, P. J., 1962. The Interpretation of Prehistoric Anthropomorphic Figurines. The Journal of the Royal Anthropological Institute of Great Britain and Ireland, 92, 1, 38-54

Ucko, P.J., 1968. Anthropomorphic Figurines of Predynastic Egypt and Neolithic Crete with Comparative Material from the Prehistoric Near East and Mainland Greece (=Royal Anthropological Institute Occasional Paper No. 24.). London: Andrew Szmidla.

Wylie, A., 1992. Feminist Theories of Social Power: Some Implications for a Processual Archaeology. Norwegian Archaeological Review, 25 (1), 51-68. DO I:10.1080/00293652.1992.9965544.

Zangger, E., 2019. James Mellaart: Pioneer and Forger. Popular Archaeology, available from: https://popular-archaeology.com/article/ james-mellaart-pioneer-and-forger/.

Zein, L. F., Setiawan, A. R., 2017. General overview of Ecofeminism. Project: Women Studies (OSF Preprints), available from: https://www. researchgate.net/publication/335441481_General_ Overview_of_Ecofeminism. 


\title{
MELLAART, GIMBUTAS, GODDESSES, AND ÇATALHÖYÜK: EARLY ASSUMPTIONS AND RECENT PERSPECTIVES ON THE ÇATALHÖYÜK FINDS
}

\author{
Nurcan Yalman
}

Summary

In this article I have summarized the relationship between the Goddess communities, who are inspired by Gimbutas' theories, and Çatalhöyük. I have also presented possible reasons why Gimbutas included the Çatalhöyük site in her theories.

In this paper I would like to give a general overview about some opposing opinions, evidence, arguments about the interpretation of the archaeological data, philosophical approaches, criticisms, etc. I explained how Mellaart claimed the existence of a mother goddess cult and a matriarchal community as well as of an elite priestly class by interpreting and sometimes deforming the Çatalhöyük finds. Then I essembled recent studies on the material which had became the subject of these goddess discussions and presented the current interpretations.
This article, while discussing studies on figurines of various forms, also includes different interpretations of the female figurines. For example, it has been argued that those female figurines may represent 'mature women' rather than a 'mother goddess'. In any case, this article discusses that we cannot reach a conclusion about the existence of a matriarchal society via female figurines. The fact that there is no difference in terms of lifestyles, nutrition, and the various features found in the burials indicates that neither woman nor man held higher social status. Therefore, it was an egalitarian society, both in terms of gender and social rank (such as elites). 


\title{
MELLAARTAS, GIMBUTIENĖ, DEIVĖS IR ČATAL HIUJUKAS: PIRMOSIOS PRIELAIDOS IR NAUJAUSIA RADINIŲ IŠ ČATAL HIUJUKO APŽVALGA
}

\author{
Nurcan Yalman
}

Santrauka

Šiame straipsnyje siekiama apibendrinti manomą ryši tarp deivių bendruomenių (pagal Marijos Gimbutienès teoriją) ir Čatal Hiujuko. Autorè taip pat svarsto galimas priežastis, dèl ko savo teorijose Gimbutienè minèjo archeologinę Čatal Hiujuko vietovę.

Šiuo darbu norima apžvelgti kai kurias priešingas nuomones, ịrodymus, argumentus dèl archeologinès medžiagos interpretavimo, filosofinius požiūrius, kritiką ir t. t. Taip pat pateikiamas paaiškinimas dèl J. Mellaarto teiginio, susijusio su matriarchine bendruomenès organizacija, deivès Motinos kulto egzistavimu, bei elitinio socialinio sluoksnio. Autorès nuomone, J. Mellaartas šiuos teiginius sukūré interpretuodamas ir kai kuriais atvejais iškreipdamas archeologinę Čatal Hiujuko medžiagą. Tekste apžvelgiami ir naujausi tyrimai, susiję su deivès kulto gyvavimo diskusijomis, pristatomos dabartinès interpretacijos. Aptariamos skirtingų formų figūrèlès, tarp kurių yra ir moters formos dirbinių. Vienoje interpretacijoje teigiama, kad moterų figūrèlès galètų vaizduoti „subrendusią moterį“, o ne „deivę Motiną“. Kad ir koks būtų atsakymas, šiame straipsnyje laikomasi nuomonès, kad išvada dèl matriarchinès bendruomenès buvimo negali būti paremta vien tik tokiais radiniais, kaip moterų figūrèlès. Kapuose nebuvo pastebėta jokių ryškių skirtumų tarp palaidotųjų gyvenimo būdo, mitybos ar kitų dalykų, o tai rodo neegzistavus ryškaus socialinio skirtumo tarp vyrų ir moterų. Manoma, jog visuomenè buvo egalitarinè tiek pagal lytí, tiek pagal socialinį sluoksni (pavyzdžiui, elitas).

Gauta: 20210929

Priimta: 20211110 